\title{
Pengenalan SIERAS pada Civitas Academica Program Studi Teknologi Informasi Universitas Amikom Purwokerto
}

\author{
Bambang Pilu Hartato*1, Agung Prakoso² ${ }^{2}$ Hasri Akbar Awal Rozaq ${ }^{3}$ \\ 1,2Program Studi Teknologi Informasi, Fakultas Ilmu Komputer, Universitas Amikom Purwokerto \\ *e-mail: bambang.pilu@amikompurwokerto.ac.id1 ${ }^{1}$, agung_student@amikompurwokerto.ac.id², \\ akbarrozaq691@gmail.com ${ }^{3}$
}

\begin{abstract}
Abstrak
Jumlah kasus COVID-19 belum menunjukkan trend penurunan. Hal tersebut mempengaruhi sektor pendidikan. Salah satu kebijakan yang diambil untuk menanggulangi dampak tersebut adalah diadakannya pembelajaran daring. Kebijakan tersebut memberikan tantangan tersendiri bagi civitas academica, tak terkecuali bagi Prodi Teknologi Informasi, Universitas Amikom Purwokerto. Salah satu perubahan yang terjadi pada proses pembelajaran yang dilakukan adalah kegiatan ujian yang harus dilakukan secara daring. Hal ini membuat pengelola prodi mencoba menggunakan beberapa teknologi untuk memenuhi kebutuhan tersebut, seperti E-Learning bernama ILIAS dan Google Form. Namun, keduanya masih memberikan kesulitan tersendiri dalam melakukan tata kelola ujian, termasuk proses penilaian yang harus dilakukan oleh dosen. Melalui kegiatan pengabdian ini, kami mencoba memperkenalkan sistem bernama SIERAS sebagai salah satu alternatif sistem tata kelola ujian. Kegiatan diikuti oleh 5 Dosen dan 20 mahasiswa. 60\% dosen menyatakan "sangat terbantu" sementara sisanya menyatakan "terbantu". Dari sisi mahasiswa, 80\%-nya menyatakan SIERAS "mudah digunakan", 15\% menyatakan "sangat mudah digunakan", dan sisanya menyatakan "cukup mudah digunakan". Dengan demikian, kegiatan pengabdian ini dinyatakan efektif dan memberikan dampak positif bagi peserta.
\end{abstract}

Kata kunci: Media Pembelajaran, Tata Kelola Ujian, COVID-19, SIERAS

\begin{abstract}
The number of COVID-19 cases has not shown a downward trend. Indeed, this affects the education sector. One of the policies taken to overcome this impact is the holding of online learning. This policy has its own challenges for the academic community, including the Department of Information Technology, Universitas Amikom Purwokerto. One of the changes that occurred in the learning process carried out was the examination activity which had to be carried out online. It makes department managers try to use several technologies to meet these needs, such as E-Learning called ILIAS and Google Form. However, both of them still provide their own difficulties in conducting examination governance, including the assessment process that must be carried out by lecturers. Through this community service activity, we are trying to introduce a system called SIERAS as an alternative exam management system. The activity was attended by 5 lecturers and 20 students. $60 \%$ of the lecturers stated that they were "very helped" while the rest stated that they were "helped". For the student side, 80\% said SIERAS was "easy to use", 15\% said it was "very easy to use", and the rest stated "quite easy to use". Thus, this service activity succeeded in achieving its goals and had a positive impact on the participants.
\end{abstract}

Keywords: Learning Media, Exam Management, COVID-19, SIERAS

\section{PENDAHULUAN}

Jumlah kasus COVID-19 hingga saat ini masih mengalami pertumbuhan setiap harinya dan belum menunjukkan trend penurunan [1]. Hal tersebut membuat berbagai sektor terkena dampaknya, termasuk sektor pendidikan [2]. Salah satu kebijakan yang diambil untuk menanggulangi dampak COVID-19 pada sektor pendidikan adalah diadakannya pembelajaran secara daring pada setiap jenjang pendidikan [3]. Tentu kebijakan tersebut memberikan tantangan tersendiri bagi setiap civitas academica, tak terkecuali civitas academica pada Program Studi Teknologi Informasi, Universitas Amikom Purwokerto.

Satu dari sekian banyak perubahan yang terjadi pada proses pembelajaran yang dilakukan oleh Program Studi Teknologi Informasi adalah kegiatan ujian tengah semester maupun ujian akhir semester yang juga harus dilakukan secara daring. Hal ini membuat Program Studi Teknologi Informasi mencoba memanfaatkan beberapa teknologi pembelajaran untuk memenuhi 
kebutuhan tersebut. Hal ini perlu dilakukan mengingat teknologi pembelajaran cukup efektif dan efisien dalam memberikan layanan pembelajaran daring termasuk dalam melakukan evaluasi pembelajarannya [4]. Teknologi yang digunakan tersebut adalah platform E-Learning bernama ILIAS [5] dan Google Form [6].

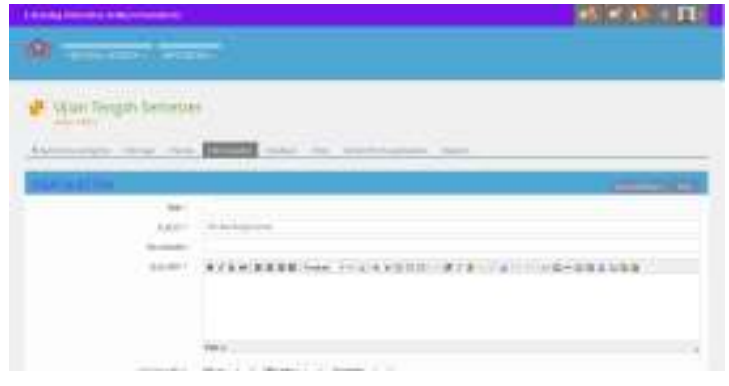

(a)

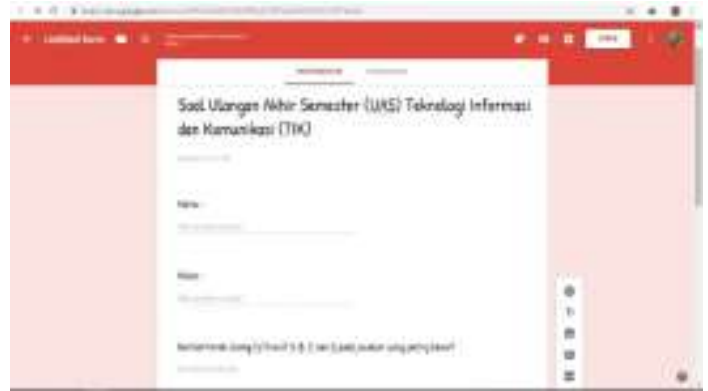

(b)

Gambar 1. Tampilan ILIAS dan Google Form

Gambar 1 (a) adalah contoh tampilan ILIAS ketika digunakan untuk mengelola ujian yang akan diberikan oleh dosen kepada mahasiswanya. ILIAS ini sebenarnya Content Management System (CMS) untuk layanan pendidikan. Sehingga baik tampilan maupun informasi yang ada di dalamnya dapat diubah sesuai kebutuhan. Sementara Gambar 1 (b) adalah tampilan Google Form yang digunakan sebagai media ujian. Secara tampilan dan penggunaan, Google Form jauh lebih sederhana dan mudah untuk digunakan. Namun, Google Form tidak dapat diatur sebebas ILIAS. Misalnya saja masalah waktu ujian. Pada ILIAS waktu ujian dapat ditentukan kapan mulai dan selesainya, sedangkan pada Google Form belum memungkinkan untuk dilakukan hal tersebut.

Walaupun demikian, kedua sistem tersebut masih memberikan kesulitan tersendiri dalam melakukan tata kelola ujian, termasuk proses penilaian yang harus dilakukan oleh dosen. Sehingga melalui kegiatan pengabdian ini, kami mencoba memperkenalkan sistem bernama SIERAS (Smart Indonesian Electronic Remote Assessment System) sebagai salah satu alternatif sistem tata kelola ujian. SIERAS sengaja dirancang untuk ujian dengan tipe essai. Tipe essai dinilai lebih objektif dalam menilai pengetahuan mahasiswa terhadap jawaban dari soal yang diajukan [7]. Terdapat dua keunggulan yang dimiliki oleh SIERAS. Pertama, SIERAS dilengkapi dengan kecerdasan buatan yang dapat membantu dosen dalam memberikan penilaian jawaban mahasiswa secara otomatis. Performa dari kecerdasan buatan yang digunakan oleh SIERAS pun terbilang cukup bagus [8]. Kedua, SIERAS dilengkapi dengan fitur Bio-enkripsi yang membuat soal dan kunci jawaban yang disediakan dosen dapat dienkripsi dengan fitur biometrik.

Perlu diketahui, SIERAS ini merupakan hasil penelitian yang telah dilakukan sebelumnya oleh tim pelaksana pengabdian.

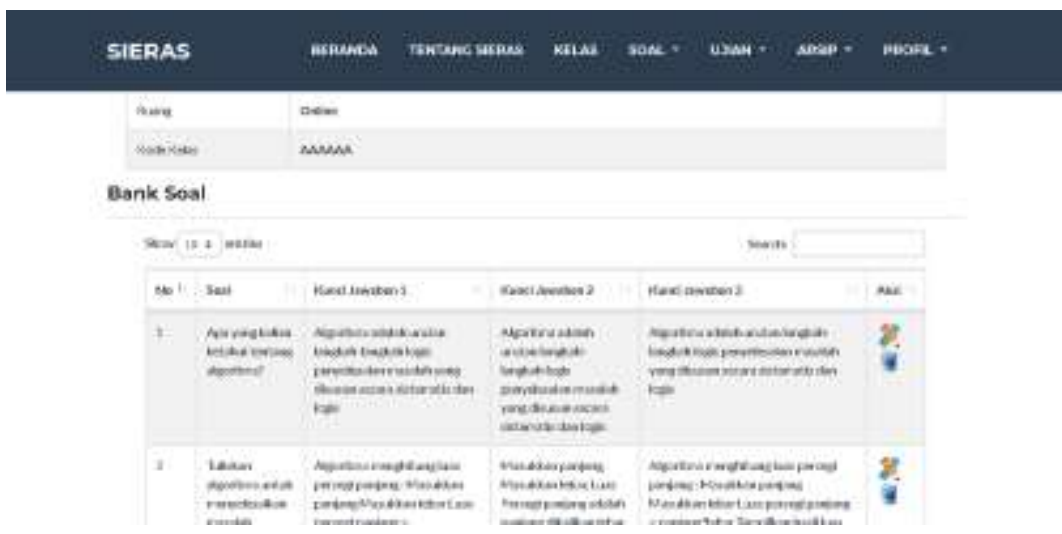

Gambar 2. Contoh tampilan SIERAS 
Pengabdian yang dilakukan ini merupakan pilot project implementasi SIERAS pada lingkungan sebenarnya. Melalui pengabdian ini kami mencoba untuk memperkenalkan SIERAS sebagai salah satu alternatif sistem tata kelola ujian yang dapat digunakan untuk mendukung konsep pembelajaran jarak jauh. Sehingga, civitas academica, khususnya yang ada di Program Studi Teknologi Informasi terbantu dalam melakukan tata kelola ujian, baik dari sisi dosen maupun dari sisi mahasiswa.

\section{METODE}

Metode pelaksanaan pengabdian ini secara garis besar menggunakan konsep workshop yang dilaksanakan selama dua hari. Pada hari pertama, tim pelaksana pengabdian memperkenalkan SIERAS kepada para peserta. Pengenalan meliputi fungsi utama dan fitur-fitur yang dimiliki oleh SIERAS dilanjutkan dengan sesi tanya jawab tentang keunggulan dan kekurangan yang dimiliki oleh SIERAS. Dari sesi tanya jawab yang dilakukan, secara tidak langsung akan memberikan masukan-masukan terhadap pengembangan SIERAS. Pada hari kedua, dilaksanakan proses simulasi ujian dengan menggunakan SIERAS. Masing-masing peserta diberi akses untuk menggunakan SIERAS yang dapat diakses melalui http://sieras.id sesuai dengan hak aksesnya. Dosen mendapat hak akses sebagai dosen, sementara kelompok mahasiswa mendapatkan akses sebagai mahasiswa.

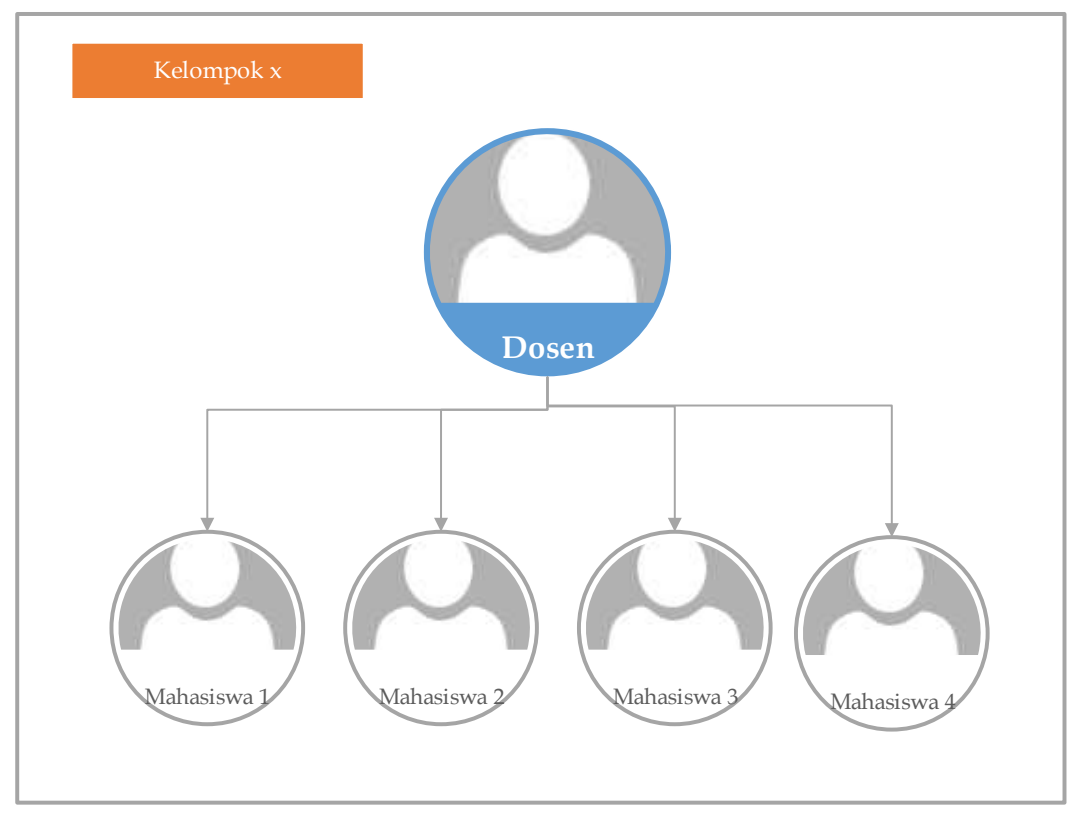

Gambar 3. Ilustrasi kelompok simulasi

Perlu diketahui, pada kegiatan pengabdian ini, peserta terdiri dari 5 dosen dan 20 mahasiswa serta semuanya berasal dari Program Studi Teknologi Informasi Universitas Amikom Purwokerto. Pada simulasi ini, peserta akan dibagi menjadi 5 kelompok. Masing-masing kelompok terdiri dari seorang dosen dan empat mahasiswa. Secara sederhana bentuk kelompok tersebut diilustrasikan pada Gambar 3. Kelompok-kelompok tersebut merepresentasikan kelas yang terdiri dari dosen dan mahasiswa. Setiap dosen diberi kesempatan untuk membuat soal pada SIERAS dengan mata kuliah yang pernah atau sedang diajarkan kepada para mahasiswanya. Selain membuat soal, dosen juga diharuskan untuk mebuat kunci jawaban yang akan digunakan oleh SIERAS untuk memeriksa jawaban siswa. Setelah soal dan kunci jawaban siap maka dosen melakukan penjadwalan ujian. Dalam hal ini, ujian disimulasikan dilaksanakan di hari kedua tersebut juga. Berikutnya mahasiswa diharuskan untuk menjawab soal sesuai dengan kelompok yang diikutinya pada periode waktu yang ditentukan. 
Setelah semua mahasiswa menjawab soal-soal yang diberikan melalui sistem SIERAS maka selanjutnya SIERAS akan menilai jawaban mahasiswa berdasarkan kunci jawaban yang disediakan oleh dosen. Walaupun proses penilaian dapat dilakukan oleh SIERAS secara otomatis, dosen harus melakukan validasi terhadap nilai yang diberikan oleh SIERAS tersebut. Hal ini untuk memastikan tidak ada kesalahan penilaian yang dilakukan oleh SIERAS.

Setelah semua simulasi yang dilakukan dirasa cukup, langkah selanjutnya adalah proses evaluasi. Kegiatan evaluasi ini dilakukan untuk menilai efektifitas dan efisiensi SIERAS dalam memambantu para dosen mengelola ujian. Selain itu, kegiatan evaluasi juga digunakan untuk menilai keberhasilan kegiatan pengabdian ini sebagai pilot project implementasi SIERAS pada Program Studi Teknlologi Informasi

\section{HASIL DAN PEMBAHASAN}

Pada bagian ini, kami menampilkan beberapa dokumentasi kegiatan yang telah dilakukan dan respon peserta kegiatan pengabdian ini. Acara dilakukan pada tanggal 27 - 28 Oktober 2020, di Ruang Eksekutif Universitas Amikom Purwokerto.

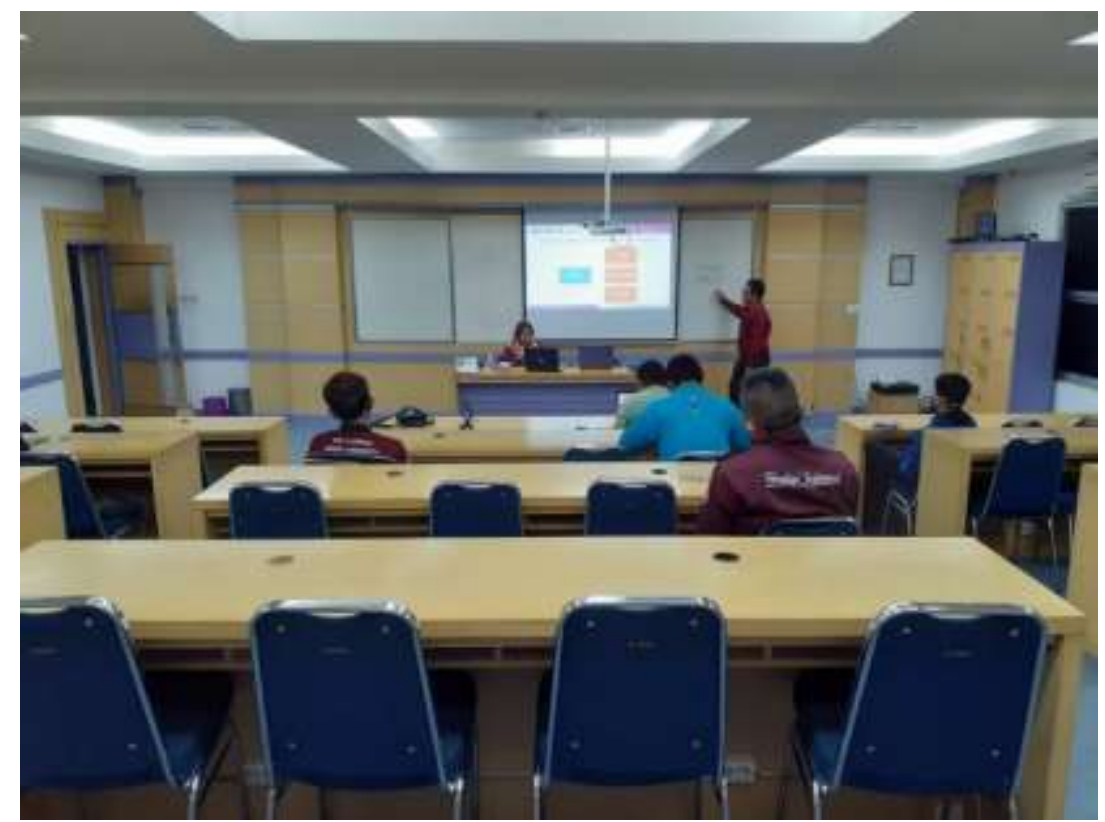

Gambar 4. Pengenalan SIERAS pada para peserta

Gambar 4 menunjukkan tim pelaksana pengabdian yang sedang memperkenalkan SIERAS kepada para peserta di hari pertama. Kegiatan tersebut dihadiri oleh 25 peserta yang terdiri dari dosen dan mahasiswa. Dikarenakan adanya aturan pembatasan jumlah orang dalam ruangan yang diterapkan, maka sebagian besar peserta mengikuti acara secara daring.
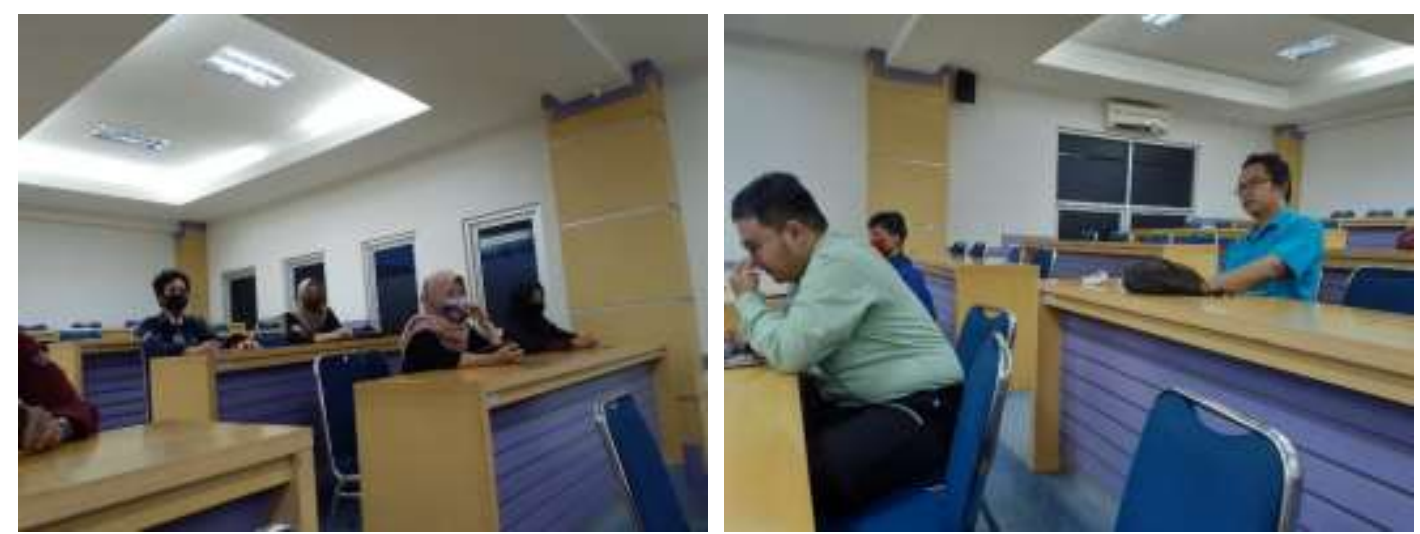

Gambar 5. Kelompok mahasiswa 
Gambar 5 menunjukkan kelompok yang terdiri dari 4 mahasiswa setiap kelompoknya. Setiap kelompok mahasiswa didampingi oleh seorang dosen. Kelompok tersebut mensimulasikan suatu kelas. Tidak semua kelompok hadir di dalam ruangan. Sebagian mengikuti secara daring melalui platform Google Meet. Seperti yang telah dijelaskan sebelumnya, setiap dosen yang mendampingi kelompok tersebut mencoba membuat soal essai dan kunci jawaban pada SIERAS sesuai dengan mata kuliah yang diampunya. Setelah soal dan kunci jawaban siap, maka soal diberikan kepada siswa melalui menu ujian yang ada pada SIERAS. Siswa dipersilahkan untuk menjawab soal yang diberikan selama periode waktu yang telah ditentukan oleh dosen.

Berikutnya, jawaban-jawaban siswa akan diperiksa oleh SIERAS secara otomatis berdasarkan kunci jawaban yang disediakan oleh dosen. Walaupun SIERAS dapat melakukan penilaian secara otomatis, dosen juga harus melakukan validasi terhadap nilai yang diberikan oleh SIERAS. Hal ini dilakukan untuk memastikan nilai yang diberikan oleh SIERAS tidak jauh berbeda dengan nilai yang harus diberikan oleh dosen. Nilai yang sudah divalidasi oleh dosen akan muncul secara otomatis pada dashboard mahasiswa, sehingga mahasiswa dapat langsung melihat nilai yang diperolehnya. Tentu proses ini jauh lebih cepat daripada proses penilaian manual. Waktu penilaian yang dibutuhkan dengan menggunakan SIERAS dapat dilakukan kurang dari satu hari, sedangkan dengan sistem penilaian manual bisa saja dilakukan selama 3 hingga 7 hari.

Setalah dosen dan mahasiswa telah selesai melakukan simulasi ujian dengan menggunakan SIERAS di hari ke-dua, dosen dan mahasiswa diminta untuk mengisi kuesioner umpan balik terhadap SIERAS dan kegiatan pengabdian yang dilakukan. Hal ini dilakukan untuk menilai efektifitas SIERAS dan juga untuk menilai keberhasilan kegiatan pengabdian ini sebagai pilot project implementasi SIERAS pada Program Studi Teknlologi Informasi.

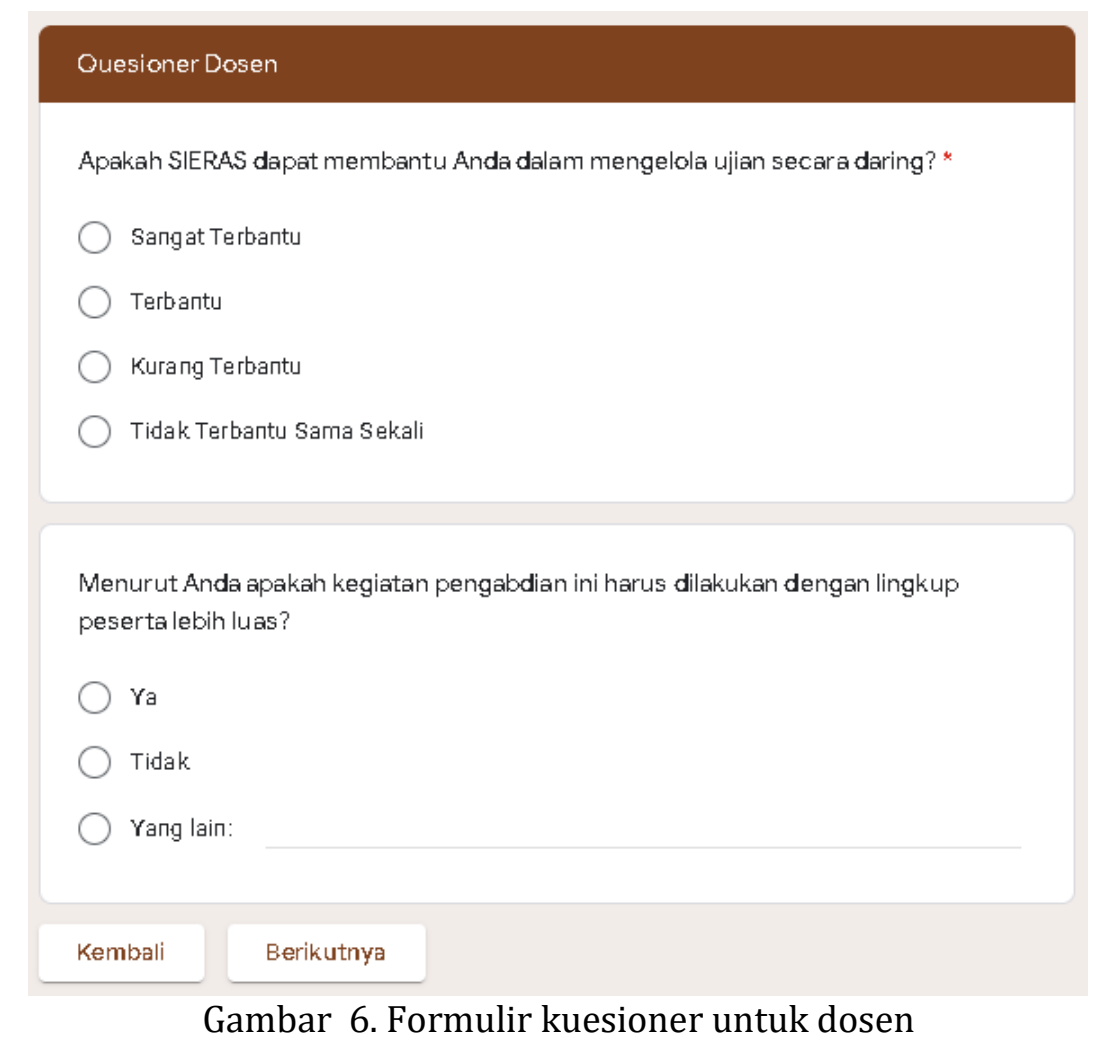

Gambar 6 adalah formulir kuesioner yang harus diisi oleh dosen peserta kegiatan pengabdian ini. Kuesioner tersebut diberikan pada hari ke-dua setelah kegiatan pengabdian ditutup. Inti dari kuesioner tersebut adalah untuk menilai apakah SIERAS dapat membantu dosen dalam mengelola ujian daring, khususnya ujian essai. Selain itu, kuesioner ini juga 
meminta pendapat para peserta terkait kemungkinan kegiatan pengabdian serupa diadakan dengan ruang lingkup lebih luas, seperti tingkat fakultas dan juga tingkat universitas.

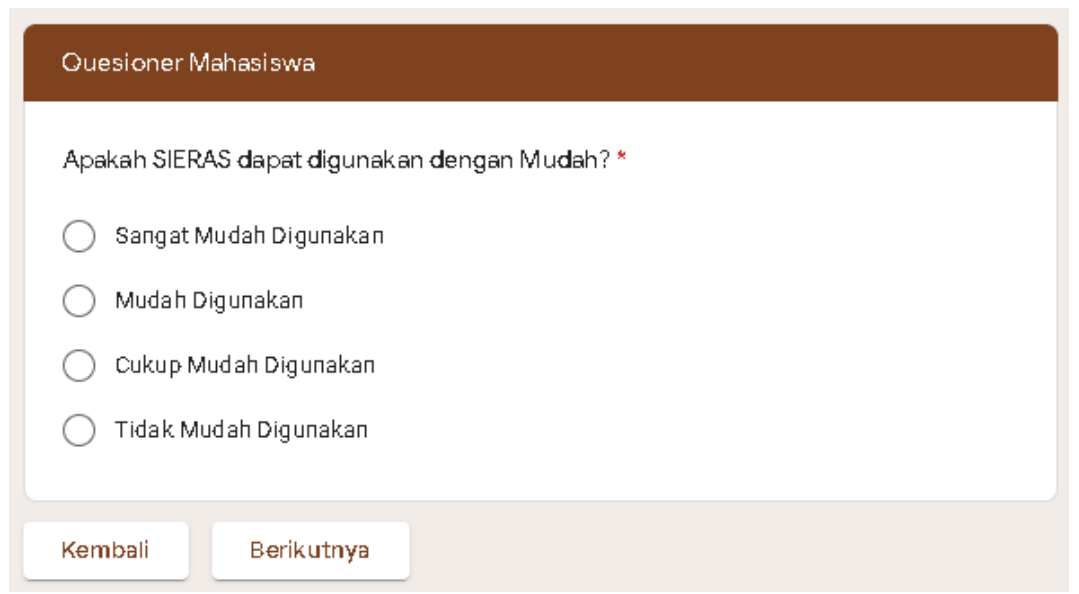

Gambar 7. Formulir kuesioner untuk mahasiswa

Gambar 7 adalah formulir kuesioner yang ditujukan untuk peserta mahasiswa. Sama dengan kuesioner untuk dosen, kuesioner ini juga diberikan kepada peserta mahasiswa di hari ke-dua setelah kegiatan pengabdian ini ditutup. Pada kuesioner mahasiswa, pertanyaan ditekankan pada aspek usability atau kemudahan penggunaan SIERAS bagi mahasiswa.

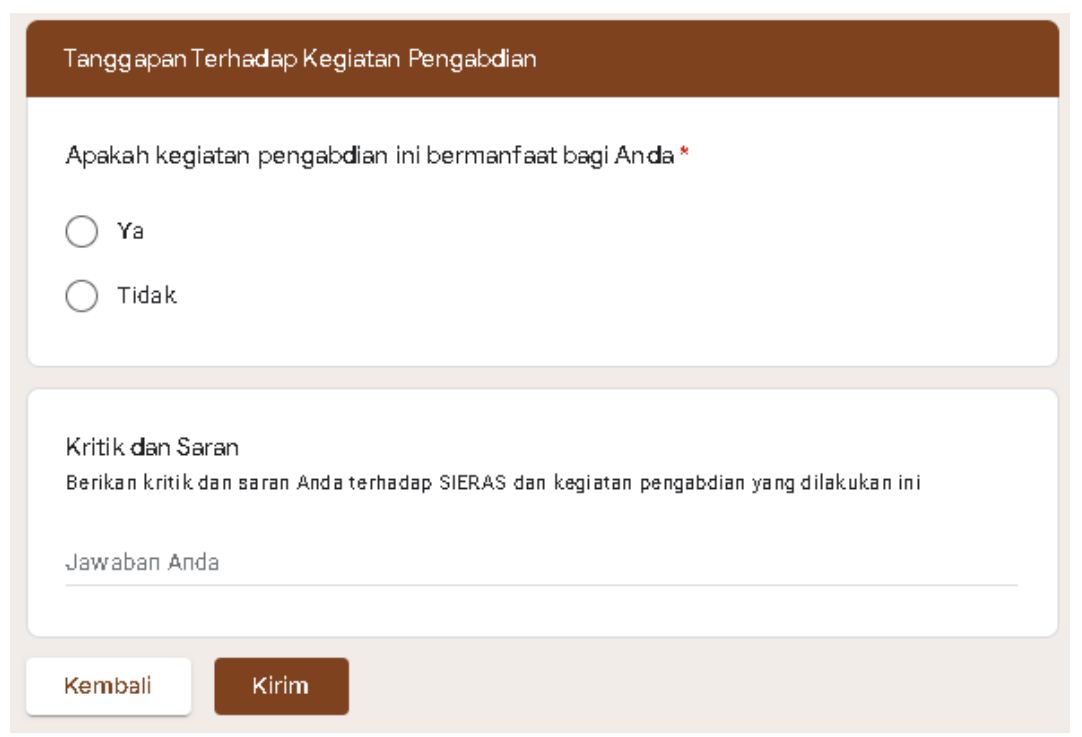

Gambar 8. Pertanyaan tambahan

Selain diberikan pertanyaan seperti yang ditunjukkan oleh Gambar 6 dan Gambar 7, para peserta juga diberi pertanyaan tambahan seperti yang ditunjukkan oleh Gambar 8. Maksud dari pertanyaan tambahan tersebut adalah untuk mendapatkan umpan balik berharga bagi pengembangan SIERAS dan kegiatan-kegiatan pengabdian selanjutnya. 


\section{Status}

25 tanggapan

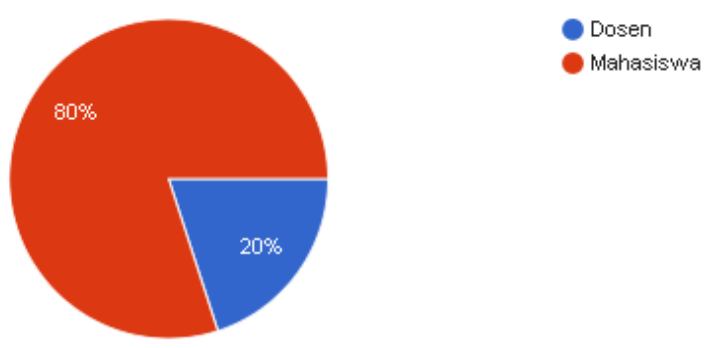

Gambar 9. Rasio responden

Gambar 9 menunjukkan rasio responden kuesioner yang telah memberikan jawabannya. Terlihat bahwa seluruh peserta termasuk dosen dan mahasiswa telah memberikan tanggapannya terkait SIERAS dan kegiatan pengabdian yang dilakukan.

\section{Quesioner Dosen}

Apakah SIERAS dapat membantu Anda dalam mengelola ujian secara daring?

5 tanggapan

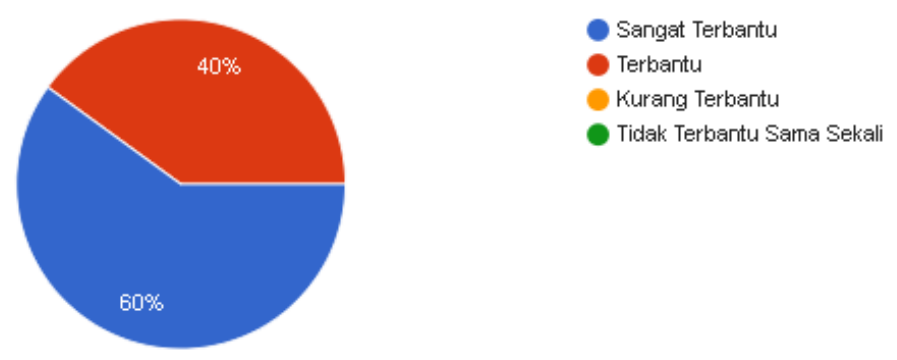

Gambar 10. Respon dosen

Gambar 10 menunjukkan respon yang diberikan dosen terhadap SIERAS. 60\% dari peserta dosen menyatakan bahwa SIERAS sangat membantu dalam mengelola ujian, sedangkan sisanya menyatakan merasa terbantu.

Quesioner Mahasiswa

Apakah SIERAS dapat digunakan dengan Mudah?

20 tanggapan

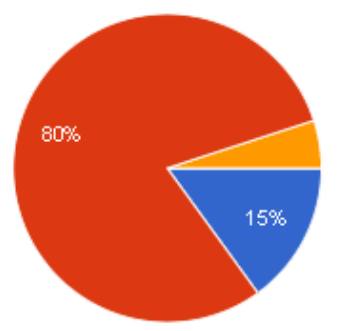

Sangat Mudah Digunakan

- Mudah Digunakan

Cukup Mudah Digunakan

- Tidak Mudah Digunakan

Gambar 11. Respon mahasiswa 
Gambar 11 adalah rasio respon yang telah diberikan oleh mahasiswa. 80\% mahasiswa yang menjadi peserta kegiatan pengabdian ini merasa SIERAS mudah digunakan, 15\% menyatakan sangat mudah digunakan, dan sisanya menyatakan cukup mudah digunakan.

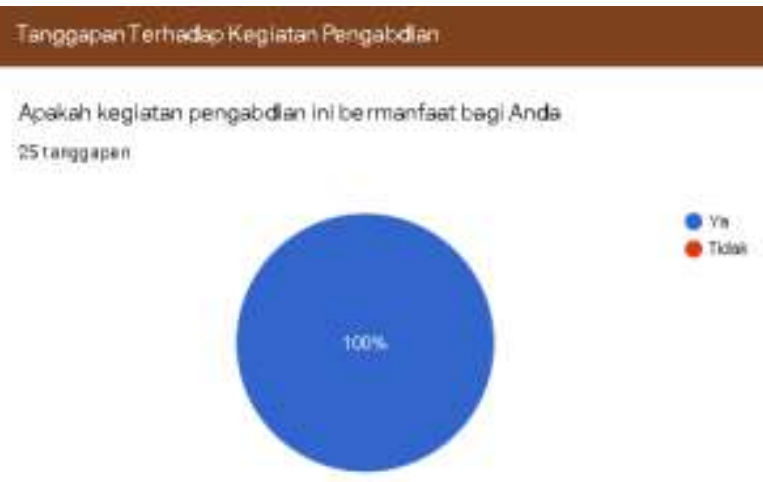

Gambar 12. Tanggapan terhadap kegiatan pengabdian

Gambar 12 menunjukkan tanggapan seluruh responden atau peserta kegiatan pengabdian terhadap kegiatan yang telah dilangsungkan. Seluruh peserta menyatakan bahwa kegiatan pengabdian ini bermanfaat bagi mereka.

\section{KESIMPULAN}

Dari hasil respon yang diberikan oleh peserta kegiatan pengabdian, dapat disimpulkan bahwa kegiatan pengabdian ini telah berhasil mencapai tujuannya, yaitu memperkenalkan SIERAS sebagai salah satu alternatif sistem manajemen ujian daring. Terlihat bahwa seluruh responden menyatakan bahwa kegiatan ini bermanfaat bagi meraka. Melihat keberhasilan tersebut, mungkin kedepannya kami akan melaksanakan kegiatan pengabdian serupa namun dengan ruang lingkup yang lebih luas, yaitu lingkup Fakultas Ilmu Komputer Universitas Amikom Purwokerto. Sehingga SIERAS harapannya dapat menjadi alternatif utama bagi dosen di lingkungan Fakultas Ilmu Komputer Universitas Amikom Purwokerto dalam membantu mengelola ujian daring. Tentu kami juga akan terus mengembangkan SIERAS sesuai dengan masukan-masukan yang telah diterima pada kegiatan pengabdian ini.

\section{UCAPAN TERIMA KASIH}

Ucapan terima kasih diberikan kepada Universitas Amikom Purwokerto yang telah mendanai seluruh kegiatan pengabdian yang telah dilakukan melalui program Hibah Amikom tahun 2020. Ucapan terima kasih juga diberikan kepada Dekan Fakultas Ilmu Komputer dan Ketua Program Studi Teknologi Informasi Universitas Amikom Purwokerto yang telah mendukung kegiatan pengabdian ini. Selain itu, ucapan terima kasih juga dipersembahkan pada Pusat Studi Sistem Cerdas Universitas Amikom Purwokerto yang telah mengontribusikan sumber dayanya dalam pelaksanaan kegiatan pengabdian ini. Tidak lupa, ucapan terima kasih juga diberikan kepada istri author pertama, Ibu Surtiningsih, yang telah membantu menyiapkan bahan untuk pemaparan dan ide-ide berharganya dalam kegiatan pengabdian ini.

\section{DAFTAR PUSTAKA}

[1] L. A. Azanella dan S. Hardiayanto, "Melihat Puncak Grafik Kasus Baru Covid-19 di Indonesia," Kompas, 2020. [Daring]. Tersedia pada: 
https://www.kompas.com/tren/read/2020/06/07/060200865/melihat-5-puncakgrafik-kasus-baru-covid-19-di-indonesia?page=all. [Diakses: 09-Jun-2020].

[2] M. Saleh, "Merdeka Belajar di Tengah Pandemi Covid-19," in Prosiding Seminar Nasional Hardiknas, 2020, hal. 51-56.

[3] B. K. dan H. Masyarakat, "Kemendikbud Imbau Pendidik Hadirkan Belajar Menyenangkan Bagi Daerah yang Terapkan Belajar di Rumah," Kemdikbud, 2020. [Daring]. Tersedia pada: https://www.kemdikbud.go.id/main/blog/2020/03/kemendikbud-imbau-pendidikhadirkan-belajar-menyenangkan-bagi-daerah-yang-terapkan-belajar-di-rumah. [Diakses: 20-Mei-2020].

[4] A. Febrianto dan N. Saputra, "Pelatihan Media Pembelajaran Inovatif dengan VideoScribe Bagi Guru SDN Malangrejo (VideoScribe)," Community Empower., vol. 6, no. 1, hal. 24-28, 2020.

[5] “International ILIAS Blog," 2020. [Daring]. Tersedia pada: https://docu.ilias.de/ilias.php?ref_id=5000\&cmd=preview\&cmdClass=ilrepositorygui\&c mdNode=mh\&baseClass=ilrepositorygui. [Diakses: 20-Mei-2020].

[6] "Mengenal Google Form untuk Kebutuhan Survey Anda," Id Cloud Host, 2016. [Daring]. Tersedia pada: https://idcloudhost.com/mengenal-google-form-untuk-kebutuhansurvey-anda/. [Diakses: 06-Feb-2020].

[7] S. Burrows, I. Gurevych, dan B. Stein, "The Eras and Trends of Automatic Short Answer Grading," Int. J. Artif. Intell. Educ., vol. 25, no. 1, hal. 60-117, 2015.

[8] U. Hasanah dan B. P. Hartato, "Assessing Short Answers in Indonesian Using Semantic Text Similarity Method and Dynamic Corpus," in 12th International Conference on Information Technology and Electrical Engineering (ICITEE), 2020, hal. 312-316. 